\title{
Protaeolidiella atra Baba, 1955 versus Pleurolidia juliae Burn, 1966: One or two species?
}

\author{
Leila Carmona - Marta Pola - Terrence M. Gosliner • \\ Juan Lucas Cervera
}

Received: 23 June 2014/Revised: 16 December 2014/ Accepted: 17 December 2014/Published online: 10 January 2015

(c) Springer-Verlag Berlin Heidelberg and AWI 2015

\begin{abstract}
Protaeolidiella atra Baba, 1955 and Pleurolidia juliae Burn, 1966 are two species traditionally regarded as the members of Aeolidiidae but recently attributed to Facelinidae. Because of their apparent similarities, Rudman (J Molluscan Stud 56:505-514, 1990) rendered $P$. juliae as a junior synonym of $P$. atra. In this paper, we conducted a review of both species and completed their descriptions with new data regarding the anatomy of the reproductive system. $P$. atra and $P$. juliae have differences in their colouration, number of cerata and characteristics of their reproductive system. Based on these differences, we conclude that these species are not conspecific and should be regarded as distinct taxa.
\end{abstract}

Keywords Facelinidae $\cdot$ Heterobranchia $\cdot$ Gastropoda . Molluscan diversity · Phylogeny · Taxonomy

Communicated by H.-D. Franke.

L. Carmona $(\varangle)$. J. L. Cervera

Departamento de Biología, Facultad de Ciencias del Mar y Ambientales, Campus de Excelencia Internacional del Mar (CEI MAR), Universidad de Cádiz, Polígono Río San Pedro, s/n, Ap. 40, 11510 Puerto Real, Cádiz, Spain

e-mail: leila.carmona@uca.es

\section{Pola}

Departamento de Biología, Edificio de Biología, Campus de Excelencia Internacional UAM+CSIC, Universidad Autónoma de Madrid, C/Darwin, 2, 28049 Madrid, Spain

T. M. Gosliner

Department of Invertebrate Zoology, California Academy of Sciences, 55 Music Concourse Drive, Golden Gate Park,

San Francisco, CA 94118, USA

\section{Introduction}

Protaeolidiella atra Baba, 1955 and Pleurolidia juliae Burn, 1966 are two species considered as the only members of these genera within the aeolid families Protaeolidiellidae Odhner, 1968 and Pleurolidiidae Burn 1966, respectively (Baba 1955; Burn 1966; Odhner 1968). Nevertheless, some authors such as Gosliner and Griffiths (1981), Rudman (1990) and Miller (2001) regarded these species as primitive members of Aeolidiidae Gray, 1827. Because of the similar appearance of these two species, differences between $P$. atra and $P$. juliae have been controversial and raised doubts about the validity of the two species and genera. According to Burn (1966), the triseriate radula of $P$. juliae is the main feature that distinguishes this species from $P$. atra. Almost three decades later, Rudman (1990) did not find any traces of lateral teeth in $P$. juliae and, therefore, concluded that both were conspecific, rendering $P$. juliae as junior synonym of $P$. atra. Baba (1992) rejected this synonymy and maintained both species as valid although he did not examine the radula of $P$. juliae. Recently, the molecular phylogeny of Aeolidiidae (Carmona et al. 2013) transferred P. juliae from Aeolidiidae to Facelinidae Bergh, 1889. This outcome concurs with the feeding behaviour of $P$. juliae, since this species, together with $P$. atra, feeds on hydroids (like most facelinids), whereas species of the Aeolidiidae all prey upon sea anemones and other anthozoans, including zoanthids (Gosliner et al. 2008).

In this contribution, we attempt to clarify the conspecifity of $P$. atra and $P$. juliae, using morphology and molecular phylogenetics including specimens from across the geographical range of both species. 


\section{Materials and methods}

Source of specimens and morphology

Samples were collected by SCUBA diving and obtained from wet collections housed at the California Academy of Sciences. Specimens were dissected by dorsal incision. Their internal features were examined and drawn under a stereoscopic microscope with the aid of a camera lucida. Special attention was given to the morphology of the reproductive system and oral and salivary glands. The buccal mass was removed and dissolved in $10 \%$ sodium hydroxide until the radula was isolated from the surrounding tissue. The radula was then rinsed in water, dried and mounted for examination under a scanning electron microscopy (SEM). The specimens examined are deposited in the California Academy of Sciences, CASIZ (San Francisco, USA) and National Museum of Nature and Science, NSMT-Mo (Ibaraki Prefecture, Japan).

\section{Molecular work}

\section{DNA extraction, amplification and sequencing}

Two specimens of $P$. atra and one $P$. juliae were studied. Twenty-five additional sequences were obtained from GenBank (see Table 1 for full list of samples, localities and vouchers), including Tritonia challengeriana Bergh, 1884 as a distant outgroup because of its basal phylogenetic position within Cladobranchia (Pola and Gosliner 2010). Tissue samples were taken from the foot. Extraction, amplification, purification and sequencing of portions of the COI, 16S rRNA and H3 genes followed the methods described in Carmona et al. (2013, 2014a, b). Sequence reactions were run on a 3730XL DNA sequencer (Applied Biosystems). Sequences were verified by forward and reverse comparisons and have been deposited in GenBank (Table 1).

\section{Sequence alignment and phylogenetic analyses}

Sequences were assembled and edited with Geneious Pro v. 4.7.6 (Drummond et al. 2009), aligned in MAFFT (Katoh et al. 2009) and further checked using MacClade v. 4.06 (Maddison and Maddison 2005). Uncorrected pairwise $p$ distance values between each taxon were calculated for the COI gene. The most variable regions from the 16S rRNA alignment were removed using the default settings in Gblocks (Talavera and Castresana 2007). Excluding "indel-rich" regions, the tree was in general poorly resolved with lower node support. Therefore, final analyses were performed including all bases. Sequences of COI, 16S and $\mathrm{H} 3$ were trimmed to 658,442 and 327 base pairs, respectively.

The best-fit evolutionary model $(\mathrm{GTR}+\mathrm{I}+\mathrm{G}$ for the three genes) was determined in MrModeltest v. 2.3 (Nylander 2004), using the Akaike information criterion (Akaike 1974). MrBayes v. 3.1.2 (Ronquist and Huelsenbeck 2003) was used for Bayesian inference analysis and to estimate posterior probabilities (PP) for node support with two runs of 5,000,000 generations each. Convergence was checked in TRACER v. 1.5 (Drummond and Rambaut 2007) with a burn-in of $25 \%$. Maximum likelihood (ML) analyses were performed using the software RAxML v7.0.4 (Stamatakis 2006), and node support was assessed with nonparametric bootstrapping (BS) with 5,000 replicates, random starting trees, and parameters estimated from each dataset under the model selected for the original dataset. Only nodes supported by BS $\geq 70$ (Hillis and Bull 1993) and $P P \geq 0.95$ (Alfaro et al. 2003) are discussed.

\section{Results}

Diagnosis of Protaeolidiella following Baba (1955)

"A somewhat aberrant genus. The general body-form is roughly as in Aeolidiella (smooth rhinophores, simply fusiform gills, broad foot with rounded corners)". But in the present genus, the branchial papillae are non-caducous and are thickly crowded on the back margins in irregular rows. As there is no distinct mantle flange, the right-sided anal opening in this genus may be considered cleioproctic (not pleuroproctic as in Coryphella). "In spite of the degenerative tendency of the jaws and radula, yet they show the fundamental structure of those in Aeolidiella. That is, the jaw plates are smooth; the central tooth of the radula is pectinated, with an emargination in the middle". Provisionally, the present new genus is classified within the family Aeolidiidae.

Protaeolidiella atra Baba, 1955

Protaeolidiella atra Baba, 1955: 53, pl. XVI, figs. 44-45, text-figs. 52-54.

Type locality: Kasajima, Sagami Bay, Japan (Fig. 1).

Type material: To our knowledge, Baba (1955) designates two syntype lots (NSMT-OpR 0872, NSMT-OpR 0884) at the National Museum of Nature and Science.

Material examined: (NSMT-Mo 78850), one specimen, adult, mature, dissected, $40 \mathrm{~mm}$ in length alive, Place Issai, Ohtsuki town Hata-gun, Kochi prefature, Japan, collected by Rie Nakano, 17.iii.12; (NSMT-Mo 78851), one specimen, adult, mature, dissected, $20 \mathrm{~mm}$ in length alive, Place 


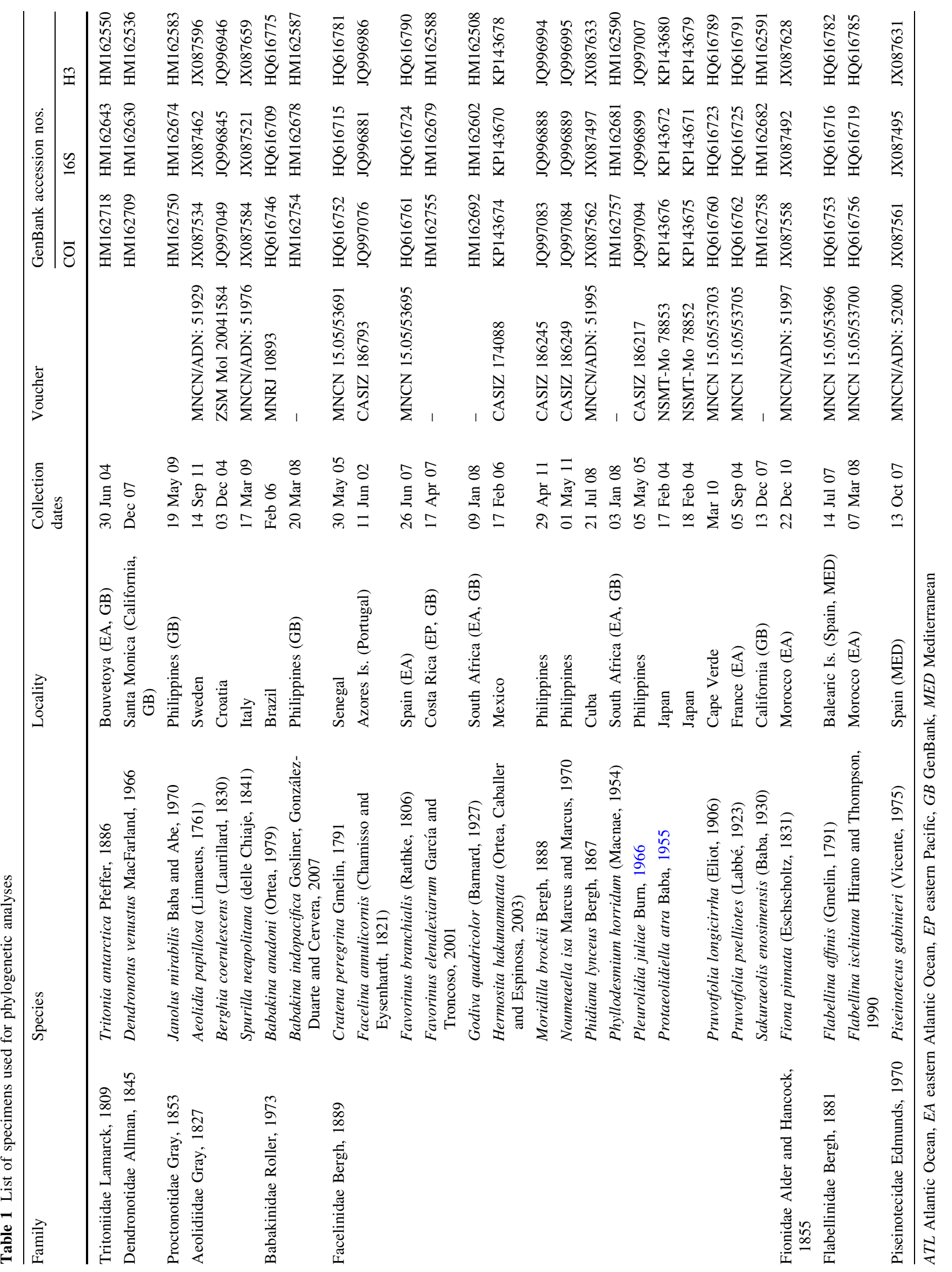


Issai, Ohtsuki town Hata-gun, Kochi prefature, Japan, collected by Rie Nakano, 17.iii.12; (NSMT-Mo 78852), one specimen, adult, mature, dissected, $40 \mathrm{~mm}$ in length alive, Zushi, Japan, collected by Michiaki Homma, 18.ii.12;

Geographical distribution: Originally described from Japan (Baba 1955; Keiu 2000; Nakano 2004), this species has been also reported in South Korea (Koh 2006; Debelius and Kuiter 2007).

External morphology (Fig. 1a, b): The body is elongate, slender and cylindrical with rounded foot corners. The body colour is quite variable, ranging from almost black to burgundy. The dorsal surface has no white pigment. The rhinophores, oral tentacles and foot corners are coloured similarly as the background of the animal. The rhinophores are smooth, shorter than the oral tentacles and have white apices. The oral tentacles are also white tipped.

The cerata densely packed along the edge of the mantle, forming a transverse row. They extend from behind the rhinophores to the posterior end of the body. The ceratal length is variable, but all are slender, cylindrical, with a round apex and uniform diameter throughout most of length. There are around 50-60 cerata per side. They have the same background colour as the body with hyaline white apices. On the right side of the body, the gonopore is situated anteriorly below the beginning of the ceratal row. The anus is on the right side of the body, in a pleuroproctic position.

Anatomy (Fig. 1c-e): The radula is uniseriate $(26 \times 0.1 .0$, NSMT-Mo 78850). The radular teeth are pectinate with 24-60 acutely pointed denticles (Fig. 1c). The latter are flattened laterally, with a similar length. The masticatory border of the jaws is smooth (Fig. 1d). Salivary and oral glands were not observed.

The reproductive system is diaulic (Fig. 1e). The hermaphroditic duct widens into an elongate and wide ampulla, which has moderately thick walls. The ampulla narrows again before dividing into the oviduct and vas deferens. The short vas deferens, which lacks a morphologically well-differentiated prostate, enters the wider proximal portion of the penial sac, which contains the unarmed penial papilla. The oviduct is moderately elongated and connects to a well-developed receptaculum seminis. The remaining portion of the oviduct separates from the base of the receptaculum and enters the female gland. The vagina opens ventrally relative to the penis.

\section{Diagnosis of Pleurolidia following Burn (1966)}

Pleuroproct Eolidacea with a triseriate radula (rachidian pectinate, laterals smooth) and smooth masticatory borders; anus in anterior third of the body length, renal pore a little in front; with rugose rhinophores and cerata, the latter with a low keel or rib on dorsal and ventral sides; penis knoblike, vas deferens prostatic, spermatheca and oviduct with separate apertures (connection probably external); nerve ring with short pedal and parapedal commissures.

Pleurolidia juliae Burn, 1966

Pleurolidia juliae Burn, 1966: 22, figs. 1-6.

Protaeolidia juliae (Burn, 1966): Gosliner et al. 2008: 402.

Type locality: “The Brook”, Lord Howe Island, Australia (Fig. 2).

Type material: According to Burn (1966), the material was deposited in the Australian Museum, Sidney. The registration number of the holotype of $P$. juliae is $\mathrm{C}$. 65661.

Material examined: CASIZ 167988, one specimen, adult, mature, dissected, $7 \mathrm{~mm}$ in length preserved, Maui, Hawaii, collected by Pauline Fiene-Severns, 12.ix.03; CASIZ 065416, one specimen, adult, mature, dissected, $11 \mathrm{~mm}$ in length preserved, Papua New Guinea, collected by Terrence M. Gosliner, 21.i.88.

Geographical distribution: This species was originally described from Lord Howe Island, Australia (Burn 1966), but it can also be found in Madagascar (Gosliner et al. 2008), Papua New Guinea (this study), Indonesia (Gosliner et al. 2008), the Philippines (Gosliner et al. 2008), Palau (Gosliner et al. 2008), and Japan (Baba 1992; Ono 1999, 2004 under the name of P. atra; Gosliner et al. 2008).

External morphology (Fig. 2a): The body is slender and cylindrical with rounded foot corners. The body colour is black and may have burgundy pigment over the head and along the back. A broad, irregular white line runs through the dorsal midline, from the head to the posterior end of the body. The oral tentacles and foot corners are coloured similarly to the background of the animal, but the oral tentacles are also tipped with white. The rhinophores are greyish, with white specks over the warts, and have white apices. They have approximately the same length as the oral tentacles.

The cerata are arranged along the edge of the mantle, forming small groups that constitute a transversal row. Sometimes these groups are not symmetrical, having a zigzag arrangement. They extend from behind the rhinophores to the posterior end of the body. The length of the cerata may vary, but all are slender, cylindrical, with round apex and uniform diameter throughout most of their length. There are around 10-20 cerata per side. They have the same background colour of the body with hyaline white 

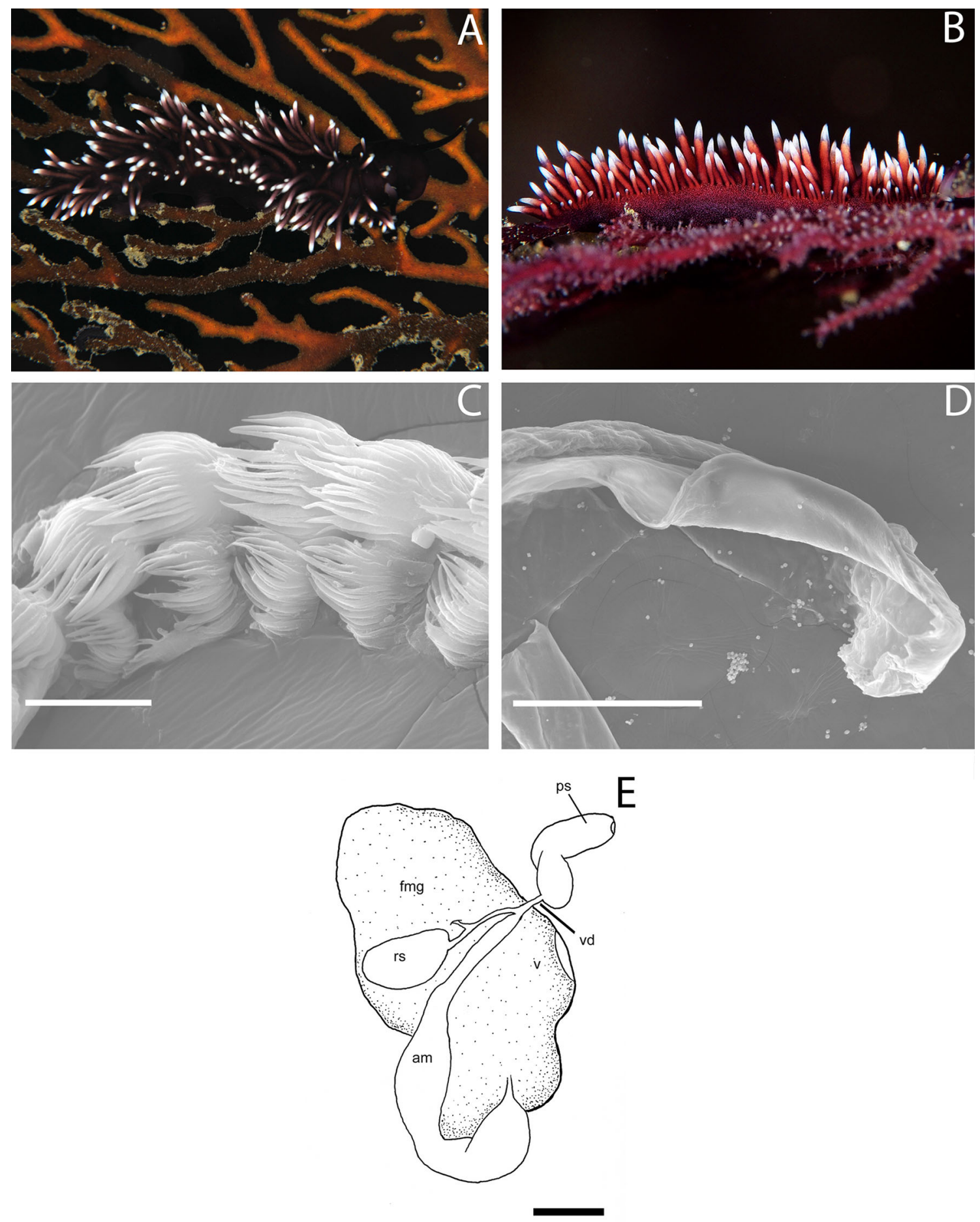

Fig. 1 Protaeolidiella atra Baba, 1955. a, b Photographs of living animals. a Specimen from Japan, photo by Michiaki Homma, (NSMT-Mo 78852); b specimen from Japan photo by Rie Nakano, (NSMT-Mo 78851). c, d Scanning electron photographs (NSMT-Mo
78850); c radular teeth, scale bar $25 \mu \mathrm{m}$; d detailed view of the masticatory border, scale bar $250 \mu \mathrm{m}$; e reproductive system (NSMTMo 78851), scale bar $0.5 \mathrm{~mm}$. am ampulla, fgm female gland mass, $p s$ penial sac, $r s$ receptaculum seminis, $v$ vagina, $v d$ vas deferens speckles over their surface. The apices are translucent white. On the right side of the body, the gonopore is placed anteriorly below the beginning of the ceratal row. The anus is on the right side of the body, in a pleuroproctic position.
Anatomy (Fig. 2b-d): The radula is uniseriate $(14 \times 0.1 .0$, CASIZ 167988). The radular teeth are pectinate with 10-12 quite long and acutely pointed denticles (Fig. 2b). The denticles are flattened laterally, with a 

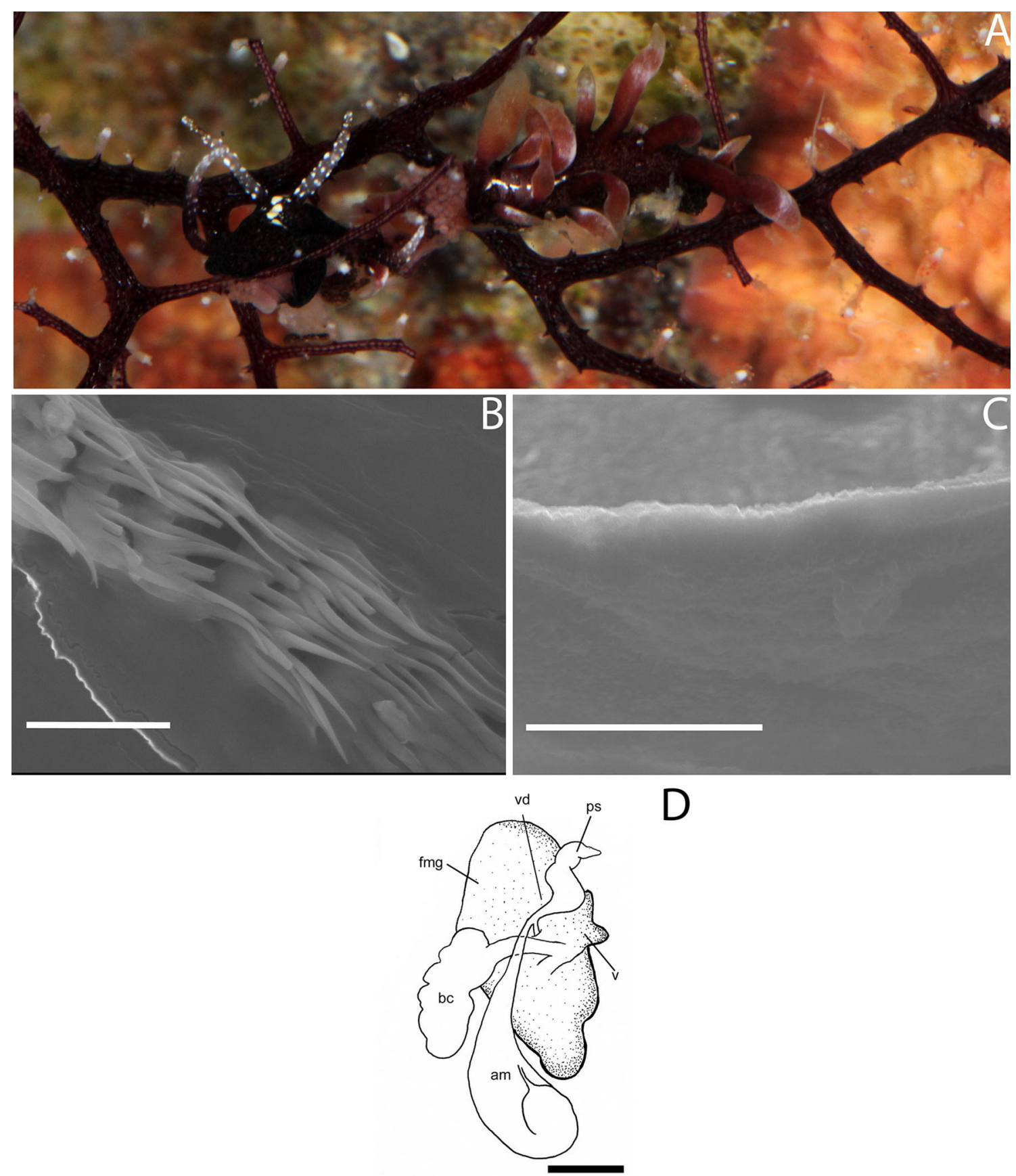

D

Fig. 2 Pleurolidia juliae Burn, 1966. a Photograph of living animal, specimen from the Philippines, photo by Terrence M. Gosliner, CASIZ 186217; b, c scanning electron photographs (CASIZ 167988), b radular teeth, scale bar $25 \mu \mathrm{m}$; c detailed view of the masticatory

similar length. The masticatory border of the jaws is finely denticulate (Fig. 2c). The oral glands are relatively large, consisting of clusters of small and rounded acini. Salivary glands were not found.

The reproductive system is diaulic (Fig. 2d). The preampullary duct widens into a large and wide ampulla, which has moderately thick walls. The ampulla narrows border, scale bar $50 \mu \mathrm{m}$; e reproductive system (CASIZ 065416) scale bar $1.5 \mathrm{~mm}$. am ampulla, $b c$ bursa copulatrix, fgm female gland mass, $p s$ penial sac, $v$ vagina, $v d$ vas deferens

again before dividing into the vas deferens and the oviduct. The short and wide vas deferens, which lacks a morphologically well-differentiated prostate, enters the wider proximal portion of the penial sac, which contains the unarmed penial papilla. The female gland mass exits at the female genital aperture, adjacent to the bursa copulatrix, which is large and exits via a relatively long, wide duct. 


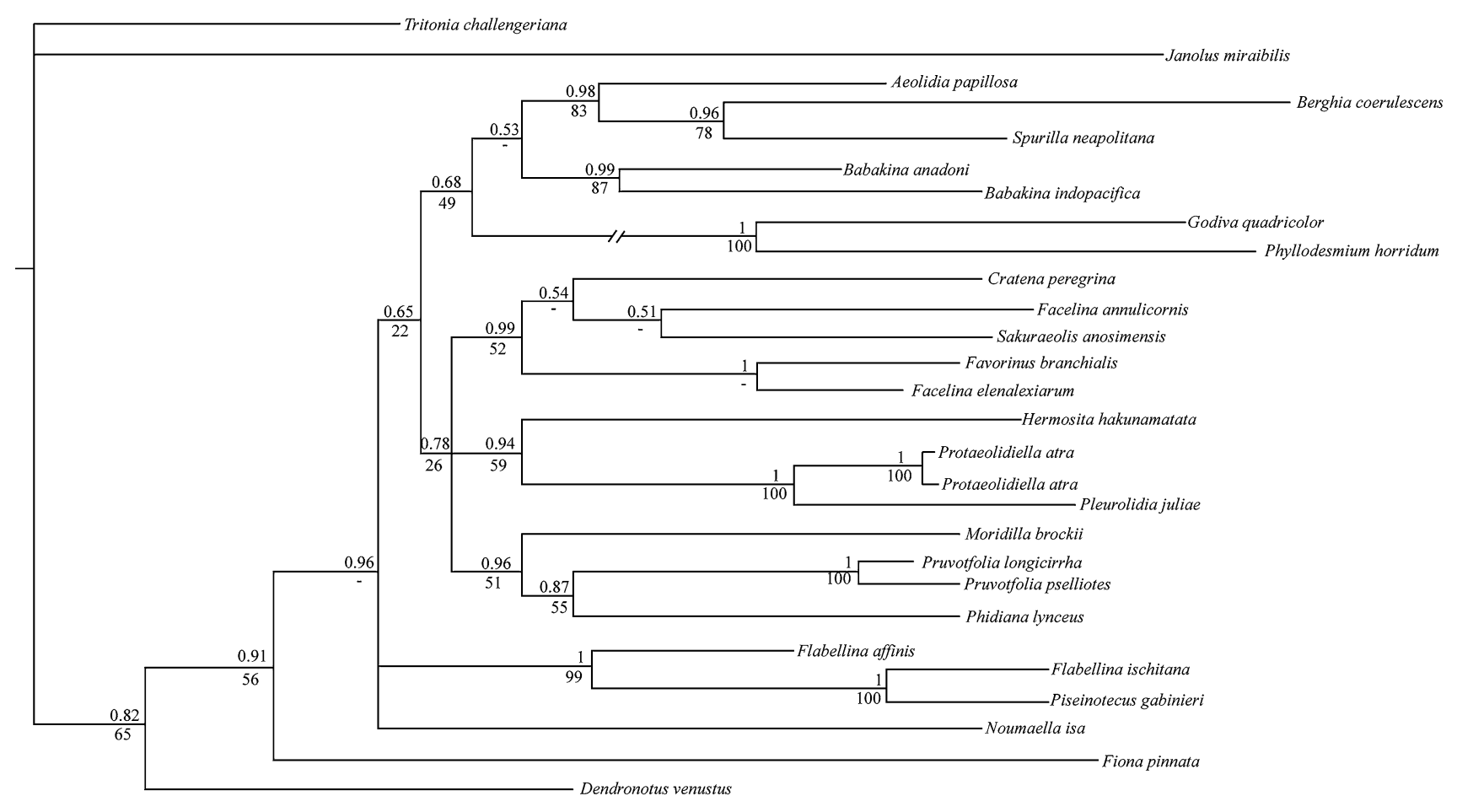

Fig. 3 Phylogenetic hypothesis for the genera Protaeolidiella and Pleurolidia based on the combined dataset $(\mathrm{H} 3+\mathrm{COI}+16 \mathrm{~S})$ inferred by Bayesian analysis (BI). Numbers above branches represent

Phylogenetic analysis

The combined dataset yielded a sequence alignment of 1,427 positions. No saturation was observed across genes and codon positions (not shown). The combined tree provided better resolution than $\mathrm{H} 3$, COI or $16 \mathrm{~S}$ separately (not shown). Bootstrap values were lower than the posterior probabilities in deeper nodes, but the topologies of the ML trees were congruent with the results yielded by the Bayesian analyses, and thus, ML trees are not shown. Figure 3 shows the resulting phylogenetic hypothesis based on the combined dataset represented by BI.

Protaeolidiella atra and $P$. juliae were nested among different facelinid species although this relationship was not supported ( $\mathrm{PP}=0.78, \mathrm{BS}=26)$. $P$. atra and P. juliae formed a single clade $(\mathrm{PP}=1, \mathrm{BS}=100)$ with Hermosita hakunamatata as its sister species $(\mathrm{PP}=0.94, \mathrm{BS}=59)$. The minimum uncorrected $p$-distance for COI between $P$. atra and P. juliae was $17.93 \%$.

\section{Discussion}

Despite differences in radular morphology, ceratal arrangement and specialised diet, Protaeolidiella and Pleurolidia have been considered as primitive aeolidiids posterior probabilities from BI. Numbers below branches represent bootstrap values from ML

(Tardy 1965; Burn 1966; Gosliner 1985). In addition, Rudman (1990) regarded $P$. juliae as a junior synonym of $P$. atra. Nevertheless, after reassessing Rudman's paper, we are strongly inclined to consider that he only studied specimens of $P$. juliae because none of these specimens were from Japan, the type locality of $P$. atra. More recently, the molecular study conducted by Carmona et al. (2013) placed P. juliae within the non-monophyletic Facelinidae, rejecting its traditional placement within the Aeolidiidae. Our anatomical and molecular results agree with those of Carmona et al. (2013) and demonstrated that the presence of morphological and genetic differences between $P$. atra and $P$. juliae. The two species can be distinguished by differences in colouration, since $P$. atra lacks the transverse and dorsal line found in $P$. juliae, as well as by the number of cerata. From an internal anatomical point of view, these species are quite similar but there is an important difference: P. atra has a receptaculum seminis, which opens into the proximal region of the gonoduct (Ghiselin 1966; Schmekel 1985; Gosliner 1994), while $P$. juliae posses a bursa copulatrix that opens into the distal region of the vaginal duct (Ghiselin 1966; Schmekel 1985; Gosliner 1994). Since Baba (1955, 1992) never depicted the reproductive system of $P$. atra and Rudman (1990), likely studied only $P$. juliae (see above), this difference in the reproductive anatomy has not been reported 
previously. In addition, we only found oral glands in $P$. juliae. Nevertheless, according to previous studies, oral glands can show some intraspecific variation in other aeolids (Carmona et al. 2014c, d), and therefore, the systematic relevance of this character should be regarded with caution. Considering the anatomical, morphological and genetic differences, we conclude that both genera are valid and monotypic. On the other hand, in order to decide about the validity of the families Protaeolidiellidae and Pleurolidiidae further information about the phylogeny of the non-monophyletic Facelinidae is needed.

The close relationship among $P$. atra, $P$. juliae and $H$. hakunamatata represents an intriguing case that warrants further study, given that these species are the only aeolids that feed on the hydroid Solanderia fusca (Gosliner personal observation). Furthermore, according to Ghiselin (1966), Gosliner (1981), Schmekel (1985) and Mikkelsen (1996), the presence of both, receptaculum semins and bursa copulatrix, represents the plesiomorphic state in the traditional "Opisthobranchia" and it is interesting to notice that $H$. hakumanatata, the only species with both anatomical structures (Millen and Hermosillo 2012), has a position as sister to the other two species within this clade. The only other species of aeolid nudibranch that has been observed feeding on species of Solanderia is Hermosita sangria Gosliner and Behrens, 1986. Future studies should examine the phylogenetic relationships of this species to the species discussed above.

Acknowledgments We are deeply grateful to R. Nakano who helped to collect and provide specimens and images for this study. Advisements of two anonymous referees contributed to improve the final version of the manuscript. This work was supported by the research grants (CGL2010-17187), Spanish Ministry of Economy and Competitiveness (includes the early Ministry of Sciences and Innovation) to J. L. Cervera. This is CEI MAR journal publication 80 .

\section{References}

Akaike H (1974) A new look at the statistical model identification. IEEE Trans Autom Control 19:716-723

Alfaro ME, Zoller S, Lutzoni F (2003) Bayes or bootstraps? A simulation study comparing the performance of Bayesian Markov chain Monte Carlo sampling and bootstrapping in assessing phylogenetic confidence. Mol Biol Evol 20:255-266

Baba K (1955) Opisthobranchia of Sagami Bay supplement. Iwanami Shoten, Tokyo

Baba K (1992) Comment on the Taxonomy of Protaeolidiella atra Baba 1955 and an allied species (Mollusca: Nudibranchia: Aeoidiidae) from Japan. Rep Sado Mar Biol Stn Niigata Univ 22:29-35

Burn R (1966) Descriptions of Australian Eolidacea (Mollusca: Opisthobranchia) 4. The genera Pleurolidia, Fiona, Learchis and Cerberilla from Lord Howe Island. J Malacol Soc Aust 10:21-34

Carmona L, Pola M, Gosliner TM, Cervera L (2013) A tale that morphology fails to tell: a molecular phylogeny of Aeolidiidae
(Aeolidida, Nudibranchia, Gastropoda). Plos One 8:e63000. doi:10.1371/journal.pone.0063000

Carmona L, Bhave V, Salunkhe R, Pola M, Gosliner TM, Cervera JL (2014a) Systematic review of Anteaeolidiella (Mollusca, Nudibranchia, Aeolidiidae) based on morphological and molecular data, with a description of three new species. Zool J Linn Soc 171:108-132

Carmona L, Lei BR, Pola M, Gosliner TM, Valdés Á, Cervera JL (2014b) Untangling the Spurilla neapolitana (Delle Chiaje, 1841) species complex: a review of the genus Spurilla Bergh, 1864 (Mollusca: Nudibranchia: Aeolidiidae). Zool J Linn Soc 171:132-154

Carmona L, Pola M, Gosliner TM, Cervera JL (2014c) Review of Baeolidia, the largest genus of Aeolidiidae (Mollusca: Nudibranchia), with the description of five new species. Zootaxa 3802:477-514

Carmona L, Pola M, Gosliner TM, Cervera JL (2014d) The end of a long controversy: systematics of the genus Limenandra (Mollusca: Nudibranchia: Aeolidiidae). Helgol Mar Res 6:37-48

Debelius H, Kuiter RH (2007) Nudibranchs of the world. IKANUnterwasserarchiv, Frankfurt

Drummond AJ, Rambaut A (2007) BEAST: Bayesian evolutionary analysis by sampling trees. BMC Evol Biol 7:214

Drummond AJ, Ashton B, Cheung M, Heled J, Kearse M, Moir R, Stones-Havas S, Thierer T, Wilson A (2009) Geneious v4.6. http://www.geneious.com/

Ghiselin MT (1966) Reproductive function and the phylogeny of opisthobranchs gastropods. Malacologia 3:327-378

Gosliner TM (1981) Origins and relationships of primitive members of the Opisthobranchia (Mollusca: Gastropoda). Biol J Linn Soc 16:197-225

Gosliner TM (1985) The Aeolid Nudibranchs family Aeolidiidae (Gastropoda, Opisthobranchia) from tropical Southern Africa. Ann S Afr Mus 95:233-267

Gosliner TM (1994) Gastropoda: Opisthobranchia. In: Harrison FW, Kohn AJ (eds) Microscopic anatomy of invertebrates, vol 5., Mollusca IWiley-Liss, New York, pp 253-355

Gosliner TM, Behrens DW (1986) Two new species and genera of aeolid nudibranchs from the tropical eastern Pacific. Veliger 29:101-113

Gosliner TM, Griffiths RJ (1981) Description and revision of some South African Aeolidacean Nudibranchia (Mollusca, Gastropoda). Ann S Afr Mus 82:102-151

Gosliner TM, Behrens DW, Valdés Á (2008) Indo-Pacific nudibranchs and sea slugs. Sea Challengers/California Academy of Sciences, Gig Harbor/San Francisco

Hillis DM, Bull JJ (1993) An empirical test of bootstrapping as a method for assessing confidence in phylogenetic analysis. Syst Biol 42:182-192

Katoh K, Asimenos G, Toh H (2009) Multiple alignment of DNA sequences with MAFFT. In: Posada D (ed) Bioinformatics for DNA sequence analysis. Methods Mol Biol 537:39-64

Keiu S (2000) Opisthobranchs of Izu Peninsula. TBS-BRITTANICA, Tokyo

Koh DB (2006) Sea slugs of Korea. Pungdeung, Pungdeung

Maddison DR, Maddison WP (2005) MacClade 4., v. 4.08 for OSX. Sinauer Associates, Sunderland

Mikkelsen PM (1996) The evolutionary relationships of Cephalaspidea s.l. (Gastropoda; Opisthobranchia): a phylogenetic analysis. Malacologia 37:375-442

Millen S, Hermosillo A (2012) Three new species of Aeolid Nudibranchs (Opisthobranchia) from the Pacific Coast of Mexico, Panama, and the Indopacific, with a redescription and redesignation of a fourth species. Veliger 51:145-164

Miller MC (2001) Aeolid nudibranchs (Gastropoda: Opisthobranchia) of the family Aeolidiidae from New Zealand waters. J Nat Hist 35:629-662 
Nakano R (2004) Opisthobranchs of Japan Islands. Rutles, Tokyo

Nylander JAA (2004) MrModeltest v2.3. Evolutionary Biology Centre, Uppsala University, Uppsala

Ono A (1999) Opisthobranchs of Kerama Islands. TBS-Britannica, Tokyo

Ono A (2004) Opisthobranchs of Ryukyu Islands. Rutles, Tokyo

Pola M, Gosliner TM (2010) The first molecular phylogeny of cladobranchian opisthobranchs (Mollusca, Gastropoda, Nudibranchia). Mol Phylogenet Evol 56:931-941

Ronquist F, Huelsenbeck JP (2003) MrBayes 3: Bayesian phylogenetic inference under mixed models. Bioinformatics 19:1572-1574

Rudman WR (1990) Protaeolidiella atra Baba 1955 and Pleurolida juliae Burn 1966; one species, two families (Nudibranchia). J Molluscan Stud 56:505-514
Schmekel L (1985) Aspects of evolution within the Opisthobranchs. The Mollusca 10:221-267

Stamatakis A (2006) RAxML-VI-HPC: maximum likelihood-based phylogenetic analyses with thousands of taxa and mixed models. Bioinformatics 22:2688-2690

Talavera G, Castresana J (2007) Improvement of phylogenies after removing divergent and ambiguously aligned blocks from protein sequence alignments. Syst Biol 56:564-577

Tardy JP (1965) Description et biologie de Cerberilla bernadetti, espèce nouvelle de Gasteropode Nudibranche de la côte atlantique française. Discussion sur la position systématique du genre. Bull Inst océanogr (Monaco) 65:1-22 